\title{
The Utilization of Active Village Health Posts in Community Health Center Rumbia, Central Lampung
}

Nanik Yuliwati, Ratu Ayu Dewi Sartika, and Anwar Hassan

Faculty of Public Health, Universitas Indonesia, Depok, Indonesia

\section{Abstract}

One of the Government's strategies to accelerate the improvement of health status is to alert the village through village health posts. Utilization of village health posts in Lampung province is the fifth lowest among all provinces in Indonesia. The scope highest people who did not utilize village health posts in Lampung was Central Lampung. Rumbia is one of the regencies in Central Lampung which Community in seeking health services by using Village Health Post is also lacking, it is seen from public visits to village health posts that only $6.7 \%$ of the total number of patient visits. This study aimed to collect information on the utilization of village health posts by the community. This research uses qualitative research design with a Rapid Assessment Procedures (RAP). The information in this research is 12 information from a community member who uses Village Health Post dan 11 essential information. Support of social media and support of community leaders to the activities village Health post less than the maximum. Most of the informants have not been utilizing the village health post with the causes of the lack of information about the existence of village health posts, there are other health facilities closer, not satisfied with the services provided, midwives were not stand by at Village health post, preferring to service private midwife and because of the public trust in one of the health workers. Knowledge cadres and midwives about the village health posts are still lacking; it is due to lack of monitoring and evaluation system for organizations and midwives.

Keywords: Qualitative, utilization, community, village health posts

\section{Introduction}

To get closer to the community-based health efforts to better achieved (accessible), more affordable (affordable), as well as higher quality (quality), government making in roads through Alert Village. (MOH, 2006).

A village is said to be idle when the rural village or urban villages have had the village health post. By $200956.1 \%$ of the 75410 villages and villages in Indonesia have started 
efforts to achieve Alert Village and the Village of Alert. However, $62.5 \%$ of households do not utilize Village health posts various reasons.

Comparable to Village health posts utilization at the national level in the province of Lampung Village health posts utilization reached $26.8 \%$ of households and is the fifth lowest of all provinces in Indonesia. Central Lampung regency has coverage Alert Village is the highest among other districts. However, whole coverage village was not accompanied by the use of Village health posts optimally by the community. Coverage people who do not take advantage of a number Village health posts highest coverage in Lampung Province.

Rumbia is one of the districts in Central Lampung regency where the people who use Village health posts still lacking, it is seen from public visits to Village health posts that only $6.7 \%$ of the total number of patient visits.

This study aimed to obtain in-depth information about people's behavior toward utilization of Village Health post activities in the District Rumbia Central Lampung regency.

\section{Methods}

The design study is a qualitative study using an in-depth interview - primary data collected from the informant that the people who use the health care facility in the village post as many as 12 people, with some keys informants group of 11 people. Secondary data collection was done through observation on infrastructure village health posts, village health post activities and workforce village health post.

The research activities carried out in two villages, namely the village Bina Karya Putra was chosen because the village is far from the District Health centers, for comparison, selected villages close to the public health center which is Rekso Binangun.

\section{Results}

The characteristic information research can see in the following table

\subsection{Utilization village health post}

Somelnformant in Bina Karya Putra village never utilizes Village Health Post, however in Rekso Binangun village most of the public never use Village Health Post.

"Not yet ma'am... I never go to Village Health Post, so I don't know how to utilize that..." (BKP2) 
TABLE 1: Informant's Characteristic Research of Utilization Active Health Village Post in Rumbia Health Center, Central LampungYear 2011.

\begin{tabular}{l|c|c|}
\hline $\begin{array}{l}\text { Informant's } \\
\text { Characteristic }\end{array}$ & Bina Karya Putra & Rekso Binangun \\
\hline Age & 23-71 years old & 22-66 years old \\
\hline $\begin{array}{l}\text { Education } \\
\text { - Low (SD-SMP) }\end{array}$ & 5 & 5 \\
\hline - High (SLTA) & 1 & 1 \\
\hline Occupation & 1 & 2 \\
\hline - Unemployed & 5 & 4 \\
\hline - Work & 2 & 1 \\
\hline Gender & 4 & 5 \\
\hline - Male & BKP 1-6 & RB 1-6 \\
\hline - Female & & \\
\hline Informant's code &
\end{tabular}

TABLE 2: Informant's Characteristic Research of Utilization Active Health Village Post in Rumbia Health Center, Central LampungYear 2011.

\begin{tabular}{l|l|c|c|c|c|}
\hline Code & Key Information & Age & Occupation & Education & Total \\
\hline C & Camat & 42 & PNS & S1 & 1 \\
\hline KP & Kepala Puskesmas & 44 & PNS & S2 & 1 \\
\hline P & Tenaga Promkes & 41 & PNS & DIII & 1 \\
\hline BD1- BD2 & Bidan Desa & $28-33$ & PTT & DIII-S1 & 2 \\
\hline KK1-2 & Kepala Kampung & $46-40$ & Kades & SMP-SMA & 2 \\
\hline TOMA1-2 & Tokoh Masyarakat & $75-48$ & Tani-PNS & SR-S1 & 2 \\
\hline KDR1-2 & Kader & $30-24$ & Unemployed & SMEA-SMA & 2 \\
\hline
\end{tabular}

Factors that cause no avail Village Health Post informant in the village Bina Karya Putra due not satisfied with the services provided, midwives are not often in place, more like a private midwife because it is considered more practical and the trust factor against health personnel desired. Rekso Binangun informant in the village did not utilize Village Health Post caused due to lack of public knowledge about the existence of a nearby village health post and for Utilizationother health care facilities.

\subsection{Knowledge of village health post}

The whole informant in the village Bina Karya Putra knows that Village Health Post there are about two or three years, which initially located in the village hall, village health post is useful for the treatment, pregnancy check, KB as PHC activities. Goal services are children, pregnant women, the elderly, FP and all walks of life. 
Most informants in the village Rekso Binangun didn't know about the existence of a village health post in the village.

"I don't know, ma'am. I just heard about this.."(RB1)

\subsection{Attitudes towards village health post}

The whole informant in states wants to try to exploit Village Health Post. The perceived benefits are easy to obtain health care and health improvement in their communities, although not optimal.

"...if I said maximal not maximal.. if I said not yet did some have done.."(KK2)

\subsection{Village health post's facilities and infrastructure}

Based on observations, all of Village Health Post facilities and infrastructure already complete. Facilities from the Department of Health Central Lampung. The forms and books have mostly been there, only a blood request form and handbooks are still limited. The whole informant who never used Village Health Post know that the infrastructure is already complete Village Health Post, facilities and support can influence them to take advantage of Village Health Post.

"..... The tools to check should be complete ma'am. If yes complete his tools would also go there..... "(BKP6)

\subsection{Village health post's staff}

\subsubsection{Cadre}

Both of Village health post has one cadre. All cadres have not trained. Knowledge gained during this cadre of Village Health Post obtained from the midwife who manages Village Health Post. Reward obtained cadres is the third part of the examination results within one month previously in the deliberations by officials from the village and other activities. Monitoring and evaluation system for cadres carried out in the form of village competition, and training of cadres has not done at the district level or the health center

"...no I didn't get trained yet...I know about this form Mrs. Julia...."(KDR1) 


\subsubsection{Midwife}

Midwives have been managing Village Health Post for one and three years. One of the midwives has trained, but it is less attended training to increase their knowledge and lack of the practice field.

"......Trainingpossesses.. just one day... it's not enough to increase knowledge..."(BDD2)

The monitoring system conducted by a team of districts for midwives done through monthly coordination meetings, and monitoring and evaluation also should be done every three months to a year once.

"Monev triwulan.. the reality is once in this year..." $(P)$

\subsection{Accessibility to the village health post}

Almost informants stated that the rate charged to them for services in Village Health Post amount seven thousand rupiah and informants felt quite affordable, patients using Jamkesmas card is also served at the village health post and not being charged at all.

Fund management in the village Rekso Binangun in 2011, up to ten thousand rupiahs previously seven thousand rupiahs, with five thousand rupiah fund management to buy drugs, and the rest is divided by three to cadres, Village Health Post and midwife managers.

The entire informants said that the distance Village Health Post with his close and not far from where they live. Almost all say that the proximity of factors can influence them to take advantage of Village Health Post.

".... Not much anyway ma'am...it's only health center nearby and in the midst of his place.. at most a quarter of an hour bu.. there are walking, riding monitor, and there is also a Necedah...... "(KDR1)

\subsection{Enabling and inhibiting factors}

\subsubsection{Family support}

The whole informant who used village health post said that the family is very supportive in this Village Health Post utilization by took medication and drove his family to Village Health Post.

"Great support.. he said not far so no need to deliver far more..." (BKP4) 


\subsubsection{Friend support}

From the information obtained partially supportive friends there to utilize Village Health Post. The support given by friends who use Village Health Post is to provide information about the activities of village health post and treatment to Village Health Post well.

"Stories that yesterday he said a bad check to a health clinic there so...." (RB5)

\subsubsection{Government support}

Government Support for this comes from the district health department is willing to call or consultation if no problems found in Village Health Post activities. Program of the District that PNPM Mandiri is prioritizing the building Village Health Post and its facilities

".... PNPM Mandiri program... poskesdes prioritize both the building and the means for its activities.. not just merely waiting for help from the government alone...." (C)

\subsubsection{Community leader support}

Most informants said that there is support from community leaders but still limited socialization and not maximized.

"Yes, it supports the bu... yes, there is a public figure busy or love to know if in this poskesdes airport treatment... but yes not all...." (BKP1)

\subsubsection{Access media support}

No socialization through electronic media and print media.

"... Posters, leaflets are also present but could not sustain all the people......... mostly counseling alone... posters posted at strategic places....." (P)

\subsection{Need (Public Demand to the Village Health Post)}

Village Health Post role in meeting the health care needs of the community it is still less, and who feel the fulfillment of requirements for health services just informants who utilize Village Health Post and activities in village health post only curative, preventive and promotive didn't do yet. 
"...... Well, start a little unfulfilled, ma'am.. especially who live far from health centers... No more personalized service, so they are also happy...." (TOMA2)

\section{Discussion}

Factors that cause the informant does not utilize Village Health Post is not satisfied with the services provided, midwives are often not in place, more like a private midwife, the trust factor against health workers is desirable, lack of information about the existence Village Health Post and because of the nearby facilities and other health services. According to JG Anderson and D.E. Bartkus (1973) in 1995 Muzaman associate utilization of health services with the individual assessment of the suitability of the various sources of health care.

Cadres have never participated in the training held earlier. The knowledge gained during this cadre obtained from the local village midwife. The is not by the technical guidelines implementation Village Health Post stating that before carrying out their duties, to the managers and cadres elected Village Health Post to be given orientation or training on the management of Village Health Post ( $\mathrm{MOH} 2008)$.

Midwives have trained, but the training acquired to increase the perceived lack of knowledge and lack of the practice field. The is according to research Guswanti (2008) which states that knowledge would affect a person's performance.

Monitoring and evaluation system village health post had been deemed not by the technical guidelines for developing and executing Village Health Post stating that coaching Village Health Post intended to maintain the operation and functioning of Village Health Post (MOH 2008).

Support community leaders are now beginning to exist, but not maximized. According to the $\mathrm{MOH}$ (2008), the role of community leaders in the village of standby is community empowerment and diggers resources for sustainability and continuity of alert village.

Provision of information about Village Health Post through print and electronic media, not maximum. From an empirical study of the relationship between communication and diffusion of innovation shows that the most powerful mass media influence the adoption during the early stages of the diffusion process (Green 1980).

Village Health Post's role in meeting the needs of public health is still less than the maximum, and who feel the fulfillment of requirements for health services the only informant who utilize Village Health Post. The is according to Suryani(2005) stated that the perception of the need for health services has a significant relationship with the rate of utilization of health services free health center in Medan. 


\section{Conclusion}

The utilization of research results that most of the informants were not utilizing the Village Health Post. Knowledge informant about Village Health Post activities is limited, as well as the village head knowledge, Community leaders, midwives, and cadres. The whole Village Health Post has had a complete infrastructure.

Cadres in Village Health Post only one person, and has never participated in the training of village health post. Midwife of Rekso Binangun had never followed training Village Health Post that is why the knowledge about village health post, not maximum.

Monitoring and evaluation system of cadres and midwives were still lacking. Most informants state that the accessibility to affordable Village Health Post's activities both in cost, distance and time.

Support families to utilize Village Health Post has been good, most of the informants said that most of his friends there who support the activities Village Health Post, government support so far has been good, the support of community leaders has been felt not maximal, support access to electronic media and print media are still very less.

\section{References}

[1] Departemen Kesehatan RI. 2009. Buku Paket Pelatihan Kader Kesehatan dan Tokoh Masyarakat Dalam Pengembangan Desa Siaga, Jakarta.

[2] Departemen Kesehatan RI. 2007. Kajian Kesiapan Petugas dan Masyarakat Dalam Pengembangan Desa Siaga, Jakarta.

[3] Departemen Kesehatan RI. 2006. Keputusan Menteri Kesehatan Republik Indonesia Nomor: 564/Menkes/Sk/Viii/2006, Pedoman Pelaksanaan Desa Siaga, Jakarta.

[4] Departemen Kesehatan RI. 2008. Kurikulum Dan Modul Pelatihan Bidan Poskesdes Dalam Pengembangan Desa Siaga, Jakarta.

[5] Departemen Kesehatan RI. 2007. Kurikulum dan Modul Pelatihan Penyiapan SDM Kesehatan dalam Pengembangan Desa Siaga, Jakarta.

[6] Departemen Kesehatan RI. 2006. Pengembangan Dan Penyelenggaraan Pos Kesehatan Desa, Jakarta, 2006

[7] Depkes RI. 2008a. Riset Kesehatan Dasar (Riskesdas) 2007, Jakarta: Depkes RI.

[8] Depkes RI,2008. Kurikulum Dan Modul Pelatihan Fasilitator Tingkat Puskesmas Dalam Pengembangan Desa Siaga, Jakarta, Depkes RI.

[9] Depkes RI.2008. Laporan Hasil Riset Kesehatan Dasar Provinsi Lampung 2007, Jakarta, Depkes. www.riskesdas.litbang.depkes.go.id 
[10] Depkes RI. 2008. Profil Kesehatan Indonesia 2008, Jakarta : Depkes RI.

[11] Depkes RI. 2008b. Survei Demografi Dan Kesehatan Indonesia 2007, Jakarta: Depkes RI.

[12] Greenley, R James.1980. Sociocultural and Psychological Aspects of The Utilization of Health Services, Dalam Assessing The Contributions of The Social Sciences to Health, Edited: M Harvey Brenner, dkk, Westview Press Inc, United States Of Amerika.

[13] Kementrian Dalam Negeri Dan Kementrian Kesehatan RI. 2010. Pedoman Umum Pengembangan Desa dan Kelurahan Aktiv, Jakarta.

[14] Kresno, Sudarti., Hadi,Ella Nurlaela., Wuryaningsih, C.Endah., Ariawan, Iwan. 2000. Aplikasi Metode Kualitatif Dalam Penelitian Kesehatan, Depok, FKM UI dan CIMUHealth The British Council.

[15] Muzaham, Fauzi. 1995. Memperkenalkan Sosiologi Kesehatan.Jakarta: Universitas Indonesia Press.

[16] Suryani, Irma. 2005. Analisis Akses Masyarakat Usia Lanjut Dalam Pemanfaatan Pelayanan Kesehatan Gratis Puskesmas Medan. Skripsi, Fakultas Kesehatan Masyarakat Universitas Indonesia.

[17] Syafrudin, Theresia EVK, Jomina. 2009. IImu Kesehatan Masyarakat. Jakarta: Trans Info Media.

[18] Tarjono. 2000. Faktor-Faktor Yang Berhubungan Dengan Pemanfaatan Fasilitas Pelayanan Kesehatan Yayasan Masyarakat Sehat Oleh Peserta Dana Sehat. Tesis, Fakultas Kesehatan Masyarakat Universitas Indonesia. 